\title{
ETHICS AND THE PUBLIC FUNCTION: EVALUATION OF LEGISLATIVE EFFECTIVENESS IN MEXICO
}

\author{
Carlos Medel Ramírez ${ }^{1}$
}

\begin{abstract}
This paper addresses the study of the ethics of responsibility in the legislative function of the Chamber of Deputies of the H. Congress of the Union, from the perspective of evaluating the work of federal deputies, and seeks to answer the following question: Is the work of the Federal Deputies in the Chamber of Deputies efficient? The purpose is how to measure and evaluate the performance in the legislative function of the Federal Deputies? and with that, to approach to identify if is the work performed by these public representatives efficient and ethical? The work is integrated in three parts. The first is the concept of the ethics of responsibility and the legislative function. In the second section, the proposal of an indicator to measure legislative efficiency is presented and the case of the federal deputies of the LXI Legislature representing the State of Veracruz of Ignacio de la Llave is analyzed. Finally, the third part presents a proposal for citizen action based on information on legislative efficiency and the need to demand compliance with ethical responsibility in the legislative function. As important conclusions of the evaluation of the legislative efficiency of the federal deputies of the LXI Legislature, it shows at least two important results: i) The legislative effectiveness index (IEL) shows very low levels, both at the plenary level of the Chamber of Deputies, as at the level of the study group of federal deputies representing the State of Veracruz. ii) In both cases, they show a very high legislative lag index. An alternative is the citizen's demand for ethical compliance with responsibility in the legislative function when knowing the evaluation of results, which serves as a reference to identify scenarios of political choice based on results.
\end{abstract}

Key words: Ethics of responsibility and legislative function, ethics in the legislative function, Legislative efficiency index

JEL K4: Legal Procedure, the Legal System, and Illegal Behavior

\footnotetext{
$1 *$ Doctor in Public Finance from the Universidad Veracruzana. Center for Studies on Public Finance and Combat Poverty. Xalapa s/n Xalapa Veracruz, Mexico. Research line: Multidimensional poverty, social exclusion and citizen empowerment. E-mail: rhdigital@hotmail.com.
} 


\section{INTRODUCTION}

In the present work the evaluation of the work of the Federal Deputies of the H. Congress of the Union is approached, from the legislative perspective, and it is about answering the following question: Is the work in the Chamber of Deputies efficient? ? The purpose of this paper is to present the elements of analysis that allow us to define the technical question of: how to measure and evaluate the ethics of responsibility in the legislative function of the Federal Deputies? and to establish if it is ethical and responsible for the work performance of public representatives?

The present work is divided into three sections. The first section presents the definition of the object of study, the ethics of legislative responsibility conferred on the Chamber of Deputies of the H. Congress of the Union of the LXI Legislature of Mexico. In the second section, the key question of our work is addressed: is the work of Federal Deputies in the Chamber of Deputies efficient? This valuation is done through the legislative efficiency index. Finally, in the third section some proposals are presented to evaluate and demand an efficient improvement in the work of the Federal Deputies of the Chamber of Deputies, by means of a simple proposal: measure to evaluate, evaluate to demand, as a citizen alternative of action and demand of results.

\section{ETHICS AND THE PUBLIC FUNCTION}

\subsection{Current debate on the ethics of conviction and the ethics of responsibility: The threshold of public service}

According to (Weber, 1959) there is currently a debate on the concept of ethics, points out that there is a debate in what he calls ethical conviction and on the other hand, in the ethics of responsibility. Weber recognizes that there is an abysmal difference between these, however he considers that the ethics of conviction and the ethics of responsibility are not contradictory, and on the contrary they complement each other and together constitute the authentic man, that is, a man who can aspire to the political vocation.

Weber asks what is morally correct and what is morally wrong? Given this conflict, it seeks to solve it with the least internal and external harm for all concerned, by focusing on the consequences of the various decisions and not on the insistence on introspective awareness. In this sense, the concept of ethics of responsibility recognizes the search rather for a political positioning, while the ethics of conviction refers only to what each of us act, according to our feelings and without explicit or implicit reference to the consequences.

As noted, the ethics of responsibility requires locating a situation, that is, considers the consequences of possible decisions and tries to introduce into the plot of events, an act that will culminate in certain results or determine certain consequences we desire. Consequently, the ethics of responsibility interprets the action in terms of means and ends.

(Mestre, 2006) defines as a responsibility a quality of a responsible in front of an obligation, in this sense, the responsible party is obliged to give an answer to an event to something. A current revision is found in (Spaemann, 1987) who identifies the ethics of responsibility as a case of moralism that leads him to consider that he presents a variable degree of ethics of conviction and ethics of responsibility, reason why he considers them as complementary . (Rhomheimer, 1994) for its part, proposes a broader vision and invites reflection between the decisions of: good and right, 
under a utilitarian approach that prioritizes decisions based on good rather than right. In this same sense, (Sánchez, 2012) identifies that the politician, who has the responsibility of the legislative function, his action entails an ethic of responsibility since he must consider the circumstances and the consequences of his acts.

What is the implication when we use the concept of responsibility ethics to the public function? and is there a particularity of ethics in the public function in the legislative field? This invites us to reflect, how to assess or measure whether the actions of the public function referred to the legislative process, is ethical or not?

In the next section we deal with the identification, from a perspective of the ethics of the responsibility of the legislative function, the form of how to evaluate it and measure the legislative efficiency, and consequently, assess whether the actions carried out by those responsible for the legislative function, by law, they fulfill the ethical responsibility conferred upon them by effective suffrage in their appointment. It is necessary to make a first dimension. Is the public function compatible with the ethics of responsibility?

First, we must define the term public function. According to the (OAS, 1996) shall be understood as any temporary or permanent activity, paid or honorary, performed by a natural person on behalf of the State or the service of the State or its entities, in any of its hierarchical levels. It is observed that its political connotation is inherent in the public space that the action of the State performs. In a clearer sense, the aspect of the public function refers to the internal disposition or self-regulation of those who perform public functions to fully comply with the postulates and mandates of the Political Constitution and the laws that indicate how this function should be exercised, in terms of efficiency, integrity, transparency and with an orientation towards the common good.

In this context, we consider that public ethics refers to the ethical guidelines that govern the performance of those who perform a public function, that is, of public officials -which includes in our case of study- those who are appointed through a popular election: federal deputies members of the H. Chamber of Deputies of the Congress of the Union.

\subsection{The ethics of legislative responsibility. Approach to the federal legislative process in Mexico}

In this section we address the study of the ethics of legislative responsibility, going into the legislative process of the Chamber of Deputies, from the perspective of the legal framework, in order to identify its meaning and its raison d'etre, such as the social representation of interests that citizens give to the Legislative Power

Article 49 of the Political Constitution of the United Mexican States establishes that the Supreme Power of the Federation is divided for its exercise in Legislative, Executive and Judicial. For its part, Article 50 defines that the legislative power is deposited in a General Congress, which is divided into two chambers: one for Deputies and one for Senators.

In this way, the Chamber of Deputies is an organ of the Legislative Power, and with powers regulated in the Political Constitution, in the Organic Law of the General Congress of the United Mexican States, in the Regulation for the Interior Government of the General Congress of the States United States and in the Parliamentary Agreements. The Chamber of Deputies is made up of representatives of the Nation, called Federal Deputies, these arise from a process of election, and have a period of action of three years. Each period of renewal in the Chamber of Deputies is called 
the Legislature, our case study corresponds to the LXI Legislature, which took effect on September 1, 2009, and ended on August 31, 2012.

The selection of this period of analysis is in virtue that it minimizes the bias of the political direction, on the part of the Federal Executive, as it happens at present with the structural reforms of: energy, communication, labor, fiscal, among others, undertaken since 2013 and that are reflected in 2014. Therefore, we consider that the selection of the LXI Legislature showed a level in its legislative process that allows us to evaluate the legislative effectiveness without counting on the political bias of the pressure of the Executive Power and the recomposition of forces within the $\mathrm{H}$. Congress of the Union, as a product of the agreements embodied in the Pact for Mexico.

The Chamber of Deputies is composed of a total of 500 deputies, of which 300 deputies are elected by principle of relative majority voting, in single-member electoral districts, and 200 are elected by the principle of proportional representation, through a system of Regional Lists. . In the LXI Legislature of the Congress of the Union, the distribution of the federal deputies, according to political party, presents the following distribution: $48.0 \%$ of the deputies are from the Institutional Revolutionary Party (PRI), 28.4\% from the National Action Party (PAN), 14.6\% of the Party of the Democratic Revolution (PRD), 4.2\% of the Partido del Verde Ecologista (PVE), 2.6\% of the Labor Party (PT), $1.6 \%$ of Convergence (CONV), $1.4 \%$ of Nueva Alianza (NA) and only $0.2 \%$ Independent. (See table 1, at the end of this document) The conformation of the federal deputies, according to their political party of origin, it is observed that $52.2 \%$ correspond to the PRI - PVEM, parties that have presented in coalition as electoral strategy, and that can consider to share the majority decision in the voting of proposals presented in the plenary session of the Chamber of Deputies, reason for which, the other minority parties must present a major lobbying activity in order to achieve the approval of their law initiatives.

In the election of deputies elected by the principle of relative majority voting, the territorial demarcation of the 300 uninominal electoral districts, which is the result of dividing the total population of the country between the districts indicated. (See table 2 at the end of this document). On the other hand, in the election of the 200 deputies according to the principle of proportional representation and the System of Regional Lists, these are constituted in five multi-member electoral districts in the country.

The Federal Deputies have the power conferred by the people to be their representative and they have the legal duty to represent the people in the legislative tasks and in those faculties conferred by the Political Constitution. From the technical-legal perspective, this is the meaning and reason of the Chamber of Deputies, but it is necessary to ask the following question: how to evaluate its performance? Do the federal deputies really obey the interests of the people who elected them? Or to what interests do the federal deputies, those of your party or those of the parliamentary branch obey? In the next section, we will seek to answer the first question, starting from the analysis of the work in the legislative process of the Federal Deputies representing the districts and districts of the State of Veracruz de Ignacio de la Llave.

\subsection{What is the legislative process? And where is the ethics of legislative responsibility located?}

A first approach to evaluate the work of the Federal Deputies is to know: what do they do ?, how is the work process organized in legislative matters ?, and the key question: is the work of the Federal Deputies in the Chamber of Deputies? From the perspective of the rights and legal faculties conferred by the Political Constitution, our first approach leads us to identify the legislative process 
and establish a way to evaluate the efficiency of Federal Deputies in the fulfillment of legislative tasks.

The legislative process is a systematic process for the preparation of federal laws, and defines a series of stages that must be observed by the Legislative Power and the Executive Power, to incorporate into the legal system those legal norms of application and general obligation. The federal legislative process is governed by the Political Constitution of the United Mexican States, the Organic Law of the General Congress of the United Mexican States and the Regulation for the Interior Government of the General Congress of the United Mexican States. At least three cases can be considered: i) constitutional reforms, ii) new laws and iii) reform of existing laws. The federal legislative process in Mexico has 6 phases: I) Right of initiative and preeminence of the place of presentation, II) Discussion, III) Approval, IV Sanction, V) Promulgation and / or publication and VI) Right of veto.

A first approach to measure and evaluate the efficiency of the Federal Deputies, is to analyze work and participation in the legislative process, and particularly, in the elaboration of initiatives whose expected final product is the formulation of laws. That is, if we consider the evaluation of the legislative process, it is through the analysis of indicators of effectiveness and / or lag, which allows us to evaluate the tasks they perform in legislative matters.

\section{EVALUATION OF LEGISLATIVE RESPONSIBILITY: APPROACH TO THE MEASUREMENT OF THE ETHICS OF LEGISLATIVE RESPONSIBILITY}

\subsection{How to measure the ethics of legislative responsibility of federal deputies? Proposal for empirical evaluation: Indicators of effectiveness and legislative backwardness}

To measure the performance of the Federal Deputies, three indicators are presented: legislative effectiveness index (IEL), legislative ineffectiveness index (INEL) and the legislative lag index (IRL).

The Legislative Effectiveness Index (IEL) is an indicator that measures the ability of each Federal Deputy to convert the initiatives presented into law. To obtain the Legislative Effectiveness Index (IEL), the different stages of the legislative process that are required for an initiative to become a law are analyzed. In this way, the information that is considered for the calculation of the index are the initiatives presented (IP) and the initiatives approved (IA). Where:

Legislative effectiveness index $($ IEL $)=($ Initiatives approved $($ IA $) /$ Initiatives presented (IP) $) \times 100$

According to the information contained in the Legislative Information System of the LXI Legislature, up to the third year of its exercise, 2,486 initiatives have been presented, only 66 initiatives have been approved. (See table 5 at the end of this document). The legislative effectiveness index is $2.65 \%$, that is, out of every 100 proposals submitted, at least 3 are approved. This value reflects a low level of efficiency of the Federal Deputies, as a whole, in the legislative process.

The legislative ineffectiveness index (INEL) is an indicator that measures the inability of each deputy to convert the initiatives presented into law. To obtain the legislative ineffectiveness index 
(INEL), the different stages of the legislative process that are required for an initiative to become a law are analyzed. In this way, the information that is considered for the calculation of the index are the initiatives presented (IP) and the initiatives rejected (ID). Where:

Legislative ineffectiveness index $($ INEL $)=($ initiatives rejected (ID) $/$ Initiatives presented (IP)) $\mathrm{x}$ 100

Of the 2,486 initiatives presented, 145 initiatives have been discarded. The legislative ineffectiveness index is $5.83 \%$, that is, out of every 100 proposals presented, at least 6 are rejected.

The legislative lag index (IRL) is an indicator that measures the level of lag in the approval of the initiatives presented by each deputy, for its conversion into law. To obtain the Legislative Effectiveness Index (LRI), the submitted initiatives (PI) and pending initiatives (IPe) are considered for the calculation of the index.

Legislative lag index $($ IRL $)=($ Initiatives pending $($ IPe $) /$ Initiatives submitted (IP) $) \times 100$

Finally, of the 2,486 initiatives presented, 2,275 initiatives are pending, in this way, the rate of legislative lag is $91.51 \%$, that is, out of every 100 proposals presented at least 92 are pending resolution. This value reflects an important lag of a large number of initiatives that are still in the process of revision, discussion and final approval.

The results presented in the previous section correspond to the total evaluation of the initiatives presented in the plenary session of the Chamber of Deputies. Here we can ask a question. What is the evaluation of the legislative effectiveness of the federal deputies representing the State of Veracruz? Hence, in the following section this dimension is presented in our subject of study.

\subsection{Case study: Evaluation of the legislative effectiveness of the federal deputies of the State of Veracruz of Ignacio de la Llave in the LXI Legislature of the H. Congress of the Union}

The annotation presented below in this work, will allow us to identify the level of legislative effectiveness of the work done by the Federal Deputies, representatives of the State of Veracruz of Ignacio de la Llave, as well as assess what has been done and where appropriate, demand the fulfillment of the duties and functions conferred by the Political Constitution, in the matter of the legislative process.

It is important to note that the Chamber of Deputies of the LXI Legislature has 29 Federal Representatives representing the districts and districts of the State of Veracruz of Ignacio de la Llave. Its distribution is as follows: $69.0 \%$ are from the PRI, $27.6 \%$ from the PAN and $3.4 \%$ from the PVEM. (See table 4 at the end of this document). Table 5 shows the allocation and distribution of the commissions in which the Federal Representatives representing the State of Veracruz of Ignacio de la Llave participate, from which it is observed that these are integrated into more than one commission, since in average participate in 3 commissions. Here is the question: What is the level of legislative effectiveness of the Federal Representatives representing the districts and circumscriptions of the State of Veracruz of Ignacio de la Llave? The results are shown below.

The 29 Federal Representatives representing Veracruz have prepared and presented 85 initiatives, of which 5 are approved initiatives and 79 initiatives are pending. (See table 6 at the end of the document). From the information presented, the following evaluation is obtained: The Legislative 
Effectiveness Index (IEL) is $5.9 \%$, this indicator measures the capacity of the deputies to convert the presented initiatives into law. On the other hand, the legislative ineffectiveness index (INEL) is only $1.2 \%$, a non-conclusive value, because of the number of initiatives rejected, it is low, compared to an index of legislative lag (IRL) of $92.9 \%$.

That is, the participation of federal deputies representing Veracruz, show a high lag value of their initiatives as these are pending processing and / or review process. In order to eliminate the bias in the interpretation of the results, when evaluating the activity as a whole of the Federal Representatives representing Veracruz, a categorization of the legislative effectiveness index (IEL) is presented below, which results from evaluating each one of the Federal Deputies, with which a more objective measurement of its legislative work is obtained. In this way, table 7 shows a qualification of the legislative work performance (See the end of this document). Finally, the evaluation of the 29 Federal Representatives representing Veracruz in the LXI Legislature shows the following results: 8 Federal Deputies show an inefficient level in their legislative work, 17 present an inefficient level, 3 show an efficient level and only 1 present an very efficient level.

The result obtained is indicative of the degree of effectiveness of the federal deputies of the Chamber of Deputies of the LXI Legislature. (See tables 8, 9, 10 and 11, at the end of the document).

These results are not flattering, however, from a broader perspective of research, the result invites us to seek to correlate the result obtained with other studies, for example, to measure the cost / benefit of the operation of the Chamber of Deputies to the light of the indicators obtained, and present new questions: How much do federal deputies cost us? Is this expense profitable with the effectiveness of your legislative work? As it is observed, this new question raises a new research work, with a greater depth of analysis, which for the moment is put on the academic discussion table.

\section{MEASURE TO EVALUATE, EVALUATE TO DEMAND. A PROPOSAL FOR ACTION AND DEMAND FOR LEGISLATIVE EFFECTIVENESS}

Under the axiom "What can not be measured, can not be evaluated", we added "What can be evaluated, its effectiveness could be demanded". The result of the evaluation of the work of the Federal Deputies of the LXI Legislature, show at least two important results:

I. The Legislative Effectiveness Index (IEL) shows very low levels, both at the plenary level of the Chamber of Deputies, and at the level of the study group of the Federal Representatives representing the State of Veracruz.

II. In both cases, they show a very high legislative lag index. In this way, the combination of these two results allows us to indicate that under the current conditions of operation, commitment and political work, it is possible to point out that the work of the Federal Deputies in the Chamber of Deputies of the LXI Legislature is not efficient. So, how to improve the level of effectiveness of federal deputies in the legislative process in the Chamber of Deputies?

The proactive action framework contemplates a simple strategy: measure to evaluate and evaluate to demand. The characteristics of the proposed strategy are presented below.

1. The first part of the strategy has been presented throughout this work, incorporating indicators for the evaluation of legislative effectiveness. With the Legislative Effectiveness Index (IEL), the legislative ineffectiveness index (INEL) and the legislative lag index (IRL), it is possible to 
have elements to measure and evaluate the legislative work of the Federal Deputies, and how it was addressed, can be applied to the set of Federal Deputies, as to each of them, in order to measure their legislative effectiveness.

2. The second part of the strategy corresponds to citizen oversight. Thus, the requirement of compliance with a legal duty embodied in the Constitution, by the electorate, will identify and define the interests of party or parliamentarians, and directing the task of the Federal Deputies to the maximum objective that is the good of the nation

\section{CONCLUSIONS}

Our research question: is the work of the Federal Deputies in the Chamber of Deputies efficient?, leads us to conclude with the evidence presented that in terms of legislative effectiveness, the work of the Federal Deputies of the LXI Legislature does not present good results The result of the evaluation of the work of the Federal Deputies of the LXI Legislature, show at least two important results: i) The Legislative Effectiveness Index (IEL) shows very low levels, both at the plenary level of the Chamber of Deputies, and at the level of the study group of the Federal Deputies representing the State of Veracruz. ii) In both cases, they show a very high legislative lag index. As an alternative solution, the measurement and citizen demand is raised to raise the level of legislative effectiveness. It follows the following conditions to seek greater effectiveness in legislative work.

I. Evaluate and demand a higher level of efficiency in the work of the Federal Deputies, in the fulfillment of the legislative tasks and

II. Achieve greater involvement of society to know if the Federal Deputies are complying or not with their obligation of legal duty, and if required, by legal means and / or through their civic will expressed in the vote, in the elections after having information and evaluation that allows them to issue a reasoned vote based on the legislative effectiveness of the political party.

III. Evaluate at the individual level, the legislative effectiveness index of the deputies and particularly of those who are elected under the principle of proportional representation, since as it is observed their level of legislative efficiency is not very efficient, thereby granting pertinent information to propose the elimination of these representatives since they do not have an operational justification.

At the level of the legislative process, the proposal for the creation of a regulation regarding the expiration of Initiatives of Law is put to the academic discussion table. Under this scheme, and the systematization of the relative information with public access, for every bill of law subject to the consideration of the Congress, that does not obtain sanction in one of its Chambers during the parliamentary year in which it had entrance, it will be considered expired and that the citizenry will have access to the state of the initiatives and bills that are of great interest to him. This action aims to streamline the legislative work and provides incentives for the professionalization of the projects presented. Therefore, for the Nation to move forward, it is an indispensable requirement, a citizen participation increasingly committed and requires

\section{REFERENCES}

Berlín Valenzuela Francisco (Coord.) y otros. (1998). Diccionario universal de términos parlamentarios. Cámara de diputados del H. Congreso de la Unión. Comité del Instituto de Investigaciones Legislativas, LVII Legislatura. Comité de Asuntos Editoriales, México. Segunda edición. ISBN 968-842-829-9. Recuperado en: http://www.diputados.gob.mx/sedia/biblio/virtual/dip/dicc_tparla/Dicc_Term_Parla.pdf consultado el 12 de octubre de 2011. 
Betancour Ma. Cristina y Cubillos Marcela. (1998). Efectividad legislativa: Cómo evaluar al gobierno y a los parlamentarios. Presentado en el panel número 6: Política y políticas públicas, en el $2^{\circ}$ Encuentro Sociedad Chilena, 19 de enero de 2011. Pontificia Universidad Católica de Chile. Santiago de Chile. Recuperado en: http://www.sociedadpoliticaspublicas.cl/archivos/BLOQUE1/Politica_y_Politicas_Publicas/E fectividad_Legislativa_Como_evaluar_al_Gobierno_y-a-los_Parlamentarios.pdf consultado el 2 de agosto de 2014.

Casar Pérez. María Amparo (2011). ¿Cómo y cuánto gasta la Cámara de Diputados? Serie: El Uso y Abuso de los Recursos Públicos. Cuaderno de debate Núm. 8 CIDE. México, septiembre 2011.

Recuperado

de: http://www.researchgate.net/publication/267565388_Cmo_y_cunto_gasta_la_Cmara_de_Dip utados consultado el 2 de agosto de 2014.

Gamboa Montejano Claudia y Valdés Robledo Sandra. (2006) Proceso legislativo. Estudio de Derecho Comparado de diversos países. LX Legislatura. Centro de Documentación, Información y Análisis Dirección de Servicios de Investigación y Análisis. Subdirección de Política Interior. México, septiembre, 2006. Recuperado de: http://www.diputados.gob.mx/sedia/sia/spi/SPI-ISS-16-06.pdf consultado el 15 de diciembre de 2014

Mestre, A. (2006). La ética de la responsabilidad según Robert Spaemann. Revista Ecclesia, XX . Número 2, págs, 227-250. Recuperado de: http://universitas.ups.edu.ec/documents/1781427/1792270/01Religion10.pdf consultado el 4 de septiembre de 2014.

Montesquieu. (1906) El espíritu de las Leyes. Trad. Siro García del Mazo. Tomo I. Biblioteca de Derecho y Ciencias Sociales. Librería General de Victoriano Suárez. Madrid. 1906. Recuperado de: http://www.google.com.mx/url?sa=t\&rct=j\&q=\&esrc=s\&frm=1\&source=web\&cd=1\&ved=0 CBwQFjAA\&url=http\%3A\%2F\%2Ffama2.us.es\%2Ffde\%2Focr\%2F2006\%2FespirituDeLas LeyesT1.pdf\&ei $=756 \mathrm{OVKKEIY-}$

UyAS01oDADA\&usg=AFQjCNFsHuf6xAHtTqxTjBHnlxWXnAfW8A consultado el 12 de octubre de 2011

Musacchio Humberto. (1989) Gran Diccionario Enciclopédico de México Visual. Tomo III, p. 1428. México.

Organización de los Estados Americanos. (1996). Convención Interamericana contra la Corrupción, OEA, Caracas, Venezuela. Recuperado de: http://www.oas.org/juridico/spanish/firmas/b-58.html consultado el 12 de octubre de 2011

Rhonheimer Martin. (1994) La prospettiva della morale. Fondamenti dell'etica filosofica. Armando, Roma, Italia. Recuperado de: https://books.google.com.mx/books?id=2i0J9HSg4EwC\&pg=PA4\&lpg=PA4\&dq=Rhonheim er+Martin.++La+prospettiva+della+morale.+Fondamenti+dell\%27etica+filosofica.+Armand o,+Roma,+Italia\&source=bl\&ots=RILO2Ke5zU\&sig=LFbi7pAkFl6qwVtrLDgtfOjcAKo\&hl $=$ es-

419\&sa $=$ X\&ei $=\mathrm{mKmOVJ7sNMecyASTxIKIDA \& ved=0CDQQ6AEwBA \# v=onepage \& q=R}$ 
honheimer\%20Martin.\%20\%20La\%20prospettiva\%20della\%20morale.\%20Fondamenti\%20 dell'etica\%20filosofica.\%20Armando\%2C\%20Roma\%2C\%20Italia\&f=false consultado el 15 de diciembre de 2014.

Sánchez, B., Jose Antonio. (2012). La ética en la función legislativa. Revista De La Facultad De Derecho De México, LXII (258), julio-diciembre, 487-508.

Spaemann Robert (1987) Ética: Cuestiones fundamentales, Eunsa, Pamplona.

Weber Max \& Mills, C. W. (1958). From Max Weber : Essays in Sociology (H. H. Gerth, Trans.). New York: Oxford University Press, Incorporated.

Weber Max (1959). Le Savant et le Politique, Le Monde, París, 10/18.p. 199. 
Table 1

Integration of the Federal Deputies, according to political party, in the Chamber of Deputies of the H. Congress of the Union. LXI Legislature.

Percentage distribution

\begin{tabular}{|c|c|c|c|}
\hline & Politic party & Integrantes & Participación \\
\hline & $\begin{array}{l}\text { Institutional Revolutionary Party } \\
\text { (PRI) }\end{array}$ & 240 & $48.0 \%$ \\
\hline & National Action Party (PAN) & 142 & $28.4 \%$ \\
\hline & $\begin{array}{l}\text { Party of the Democratic Revolution } \\
\text { (PRD) }\end{array}$ & 68 & $13.6 \%$ \\
\hline & $\begin{array}{l}\text { Green Party Ecologist of Mexico } \\
\text { (PVEM) }\end{array}$ & 21 & $4.2 \%$ \\
\hline & Labor Party (PT) & 13 & $2.6 \%$ \\
\hline & Convergence (CONV) & 8 & $1.6 \%$ \\
\hline & New Alliance (NA) & 7 & $1.4 \%$ \\
\hline & Without political party (SP) & 1 & $0.2 \%$ \\
\hline & TOTAL & 500 & $100.0 \%$ \\
\hline
\end{tabular}

Source:

Chamber of Deputies. H. Congress of the Union. List of Deputies by Parliamentary Group.

Recovered from: http://sitl.diputados.gob.mx/LXI_leg/listado_diputados_gpnp.php?tipo=TOTAL 
Table 2

Integration of Federal Deputies by Relative Majority and Proportional Representation, according to political party, representatives of the State of Veracruz of Ignacio de la Llave in the Chamber of Deputies. H. Congress of the Union. LXI Legislature,

\begin{tabular}{|c|c|c|c|c|c|c|c|c|c|}
\hline & Politic party & $\begin{array}{l}\text { Integran- } \\
\text { tes }\end{array}$ & $\begin{array}{l}\text { Parti- } \\
\text { cipación }\end{array}$ & Distrito & $\begin{array}{l}\text { Circuns- } \\
\text { cripción }\end{array}$ & Total & Distrito & $\begin{array}{l}\text { Circuns- } \\
\text { cripción }\end{array}$ & Total \\
\hline & $\begin{array}{l}\text { Institutional } \\
\text { Revolutionary } \\
\text { Party (PRI) }\end{array}$ & 240 & $48.0 \%$ & 187 & 53 & 240 & $77.9 \%$ & $22.1 \%$ & $100.0 \%$ \\
\hline & $\begin{array}{c}\text { National Action } \\
\text { Party (PAN) }\end{array}$ & 142 & $28.4 \%$ & 68 & 74 & 142 & $47.9 \%$ & $52.1 \%$ & $100.0 \%$ \\
\hline & $\begin{array}{l}\text { Party of the } \\
\text { Democratic } \\
\text { Revolution } \\
\text { (PRD) }\end{array}$ & 68 & $13.6 \%$ & 37 & 31 & 68 & $54.4 \%$ & $45.6 \%$ & $100.0 \%$ \\
\hline & $\begin{array}{c}\text { Green Party } \\
\text { Ecologist of } \\
\text { Mexico (PVEM) }\end{array}$ & 21 & $4.2 \%$ & 4 & 17 & 21 & $19.1 \%$ & $80.9 \%$ & $100.0 \%$ \\
\hline & $\begin{array}{l}\text { Labor Party } \\
\text { (PT) }\end{array}$ & 13 & $2.6 \%$ & 3 & 10 & 13 & $23.1 \%$ & $76.9 \%$ & $100.0 \%$ \\
\hline & $\begin{array}{l}\text { Convergence } \\
\text { (CONV) }\end{array}$ & 8 & $1.6 \%$ & 1 & 7 & 8 & $12.5 \%$ & $87.5 \%$ & $100.0 \%$ \\
\hline & $\begin{array}{c}\text { New Alliance } \\
\text { (NA) }\end{array}$ & 7 & $1.4 \%$ & 0 & 7 & 7 & $0.0 \%$ & $100.0 \%$ & $100.0 \%$ \\
\hline & $\begin{array}{c}\text { Without } \\
\text { political party } \\
\text { (SP) }\end{array}$ & 1 & $0.2 \%$ & 0 & 1 & 1 & $0.0 \%$ & $100.0 \%$ & $100.0 \%$ \\
\hline & TOTAL & 500 & $100.0 \%$ & 300 & 200 & 500 & $60.0 \%$ & $40.0 \%$ & $100.0 \%$ \\
\hline
\end{tabular}

Source:

Chamber of Deputies. H. Congress of the Union. List of Deputies by Parliamentary Group.

Recovered from: http://sitl.diputados.gob.mx/LXI leg/listado_diputados_gpnp.php?tipo=TOTAL 
Table 3

Initiatives presented by the Federal Deputies by relative majority and proportional representation, according to political party, in the Chamber of Deputies of the H. Congress of the Union. LXI Legislature

Percentage distribution

\begin{tabular}{|c|c|c|c|c|c|c|c|c|c|}
\hline & Politic party & $\begin{array}{c}\text { Presen } \\
\text { ted }\end{array}$ & Slopes & $\begin{array}{l}\text { Appro } \\
\text { ved }\end{array}$ & $\begin{array}{c}\text { Discar } \\
\text { ded }\end{array}$ & $\begin{array}{l}\text { Legislati } \\
\text { ve } \\
\text { Effecti } \\
\text { veness } \\
\text { Index }\end{array}$ & $\begin{array}{l}\text { Index of } \\
\text { Legislati } \\
\text { ve Non- } \\
\text { Effectiv } \\
\text { eness }\end{array}$ & $\begin{array}{c}\text { Index of } \\
\text { Legislati } \\
\text { ve Lag }\end{array}$ & $\begin{array}{l}\text { Total } \\
\text { Index }\end{array}$ \\
\hline & $\begin{array}{l}\text { Institutional } \\
\text { Revolutionary } \\
\text { Party (PRI) }\end{array}$ & 918 & 850 & 22 & 46 & $2.4 \%$ & $5.0 \%$ & $92.6 \%$ & $100.0 \%$ \\
\hline & $\begin{array}{c}\text { National Action } \\
\text { Party (PAN) }\end{array}$ & 526 & 487 & 14 & 25 & $2.7 \%$ & $4.7 \%$ & $92.6 \%$ & $100.0 \%$ \\
\hline 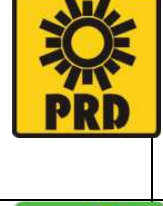 & $\begin{array}{l}\text { Party of the } \\
\text { Democratic } \\
\text { Revolution } \\
\text { (PRD) }\end{array}$ & 380 & 349 & 14 & 17 & $3.7 \%$ & $4.5 \%$ & $91.8 \%$ & $100.0 \%$ \\
\hline$D=$ & $\begin{array}{c}\text { Green Party } \\
\text { Ecologist of } \\
\text { Mexico } \\
\text { (PVEM) }\end{array}$ & 211 & 196 & 9 & 6 & $4.3 \%$ & $2.8 \%$ & $92.9 \%$ & $100.0 \%$ \\
\hline & $\begin{array}{l}\text { Labor Party } \\
\text { (PT) }\end{array}$ & 181 & 165 & 2 & 14 & $1.1 \%$ & $7.7 \%$ & $91.2 \%$ & $100.0 \%$ \\
\hline & $\begin{array}{c}\text { Convergence } \\
(\text { CONV) }\end{array}$ & 53 & 50 & 1 & 2 & $1.9 \%$ & $3.8 \%$ & $94.3 \%$ & $100.0 \%$ \\
\hline 20) & $\begin{array}{l}\text { New Alliance } \\
\text { (NA) }\end{array}$ & 203 & 167 & 4 & 32 & $1.9 \%$ & $15.8 \%$ & $82.3 \%$ & $100.0 \%$ \\
\hline & $\begin{array}{c}\text { Without } \\
\text { political party } \\
\text { (SP) }\end{array}$ & 14 & 11 & 0 & 3 & $0.0 \%$ & $21.4 \%$ & $78.6 \%$ & $100.0 \%$ \\
\hline & TOTAL & 2,486 & 2,275 & 66 & 145 & $2.7 \%$ & $5.8 \%$ & $91.5 \%$ & $100.0 \%$ \\
\hline
\end{tabular}

Source:

Chamber of Deputies. H. Congress of the Union. List of Deputies by Parliamentary Group.

Recovered from: http://sitl.diputados.gob.mx/LXI leg/listado diputados gpnp.php?tipo=TOTAL 


\section{Table 4}

Integration of Federal Deputies by Relative Majority and Proportional Representation, according to political party, representatives of the State of Veracruz of Ignacio de la Llave in the Chamber of

Deputies. H. Congress of the Union. LXI Legislature,

September 2011

\begin{tabular}{|c|c|c|c|c|c|c|c|c|c|}
\hline & Politic party & Members & $\begin{array}{c}\text { Participatio } \\
n\end{array}$ & District & $\begin{array}{l}\text { Circums } \\
\text { cription }\end{array}$ & Total & District & $\begin{array}{l}\text { Circums } \\
\text { cription }\end{array}$ & Total \\
\hline C & $\begin{array}{l}\text { Institutional } \\
\text { Revolutionary } \\
\text { Party (PRI) }\end{array}$ & 20 & $69.0 \%$ & 17 & 3 & 20 & $85.0 \%$ & $15.0 \%$ & $100.0 \%$ \\
\hline & $\begin{array}{l}\text { National Action } \\
\text { Party (PAN) }\end{array}$ & 8 & $27.6 \%$ & 4 & 4 & 8 & $50.0 \%$ & $50.0 \%$ & $100.0 \%$ \\
\hline & $\begin{array}{l}\text { Party of the } \\
\text { Democratic } \\
\text { Revolution } \\
\text { (PRD) }\end{array}$ & 0 & $0.0 \%$ & 0 & 0 & 0 & $0.0 \%$ & $0.0 \%$ & $0.0 \%$ \\
\hline & $\begin{array}{c}\text { Green Party } \\
\text { Ecologist of } \\
\text { Mexico } \\
\text { (PVEM) } \\
\end{array}$ & 1 & $3.4 \%$ & 0 & 1 & 1 & $0.0 \%$ & $\begin{array}{c}100.0 \\
\%\end{array}$ & $100.0 \%$ \\
\hline & $\begin{array}{l}\text { Labor Party } \\
\qquad(\mathrm{PT})\end{array}$ & 0 & $0.0 \%$ & 0 & 0 & 0 & $0.0 \%$ & $0.0 \%$ & $0.0 \%$ \\
\hline & $\begin{array}{c}\text { Convergence } \\
(\mathrm{CONV})\end{array}$ & 0 & $0.0 \%$ & 0 & 0 & 0 & $0.0 \%$ & $0.0 \%$ & $0.0 \%$ \\
\hline alianzza & $\begin{array}{l}\text { New Alliance } \\
\text { (NA) }\end{array}$ & 0 & $0.0 \%$ & 0 & 0 & 0 & $0.0 \%$ & $0.0 \%$ & $0.0 \%$ \\
\hline & $\begin{array}{c}\text { Without } \\
\text { political party } \\
\text { (SP) }\end{array}$ & 0 & $0.0 \%$ & 0 & 0 & 0 & $0.0 \%$ & $0.0 \%$ & $0.0 \%$ \\
\hline & TOTAL & 29 & $100.0 \%$ & 21 & 8 & 29 & $72.0 \%$ & $28.0 \%$ & $100.0 \%$ \\
\hline
\end{tabular}

Source:

Chamber of Deputies. H. Congress of the Union. List of Deputies by Parliamentary Group.

Recovered from: http://sitl.diputados.gob.mx/LXI_leg/listado_diputados_gpnp.php?tipo=TOTAL 
Table 5

Distribution and integration of Commissions of the Federal Deputies for Relative Majority and Proportional Representation of the State of Veracruz of Ignacio de la Llave in the Chamber of Deputies. H. Congresses of the Union. LXI Legislature.

\begin{tabular}{|c|c|c|c|c|}
\hline Commissions & PR & P: & $\frac{9}{19}$ & Total \\
\hline Agrarian reform & 2 & 0 & 0 & 2 \\
\hline Agriculture and Livestock & 1 & 0 & 0 & 1 \\
\hline Attention to vulnerable groups & 3 & 0 & 0 & 3 \\
\hline Budget and public account & 1 & 0 & 0 & 1 \\
\hline Citizen participation & 1 & 0 & 0 & 1 \\
\hline Communications & 2 & 0 & 1 & 3 \\
\hline Constitutional points & 1 & 0 & 0 & 1 \\
\hline $\begin{array}{l}\text { Cooperative development and social } \\
\text { economy }\end{array}$ & 1 & 1 & 0 & 2 \\
\hline Culture & 2 & 0 & 0 & 2 \\
\hline Energy & 3 & 2 & 0 & 5 \\
\hline Environment and natural resources & 1 & 1 & 0 & 2 \\
\hline Equity and gender & 2 & 0 & 0 & 2 \\
\hline External relationships & 1 & 0 & 0 & 1 \\
\hline Fishing & 2 & 1 & 0 & 3 \\
\hline Health & 1 & 1 & 0 & 2 \\
\hline Hydraulic resources & 1 & 2 & 0 & 3 \\
\hline Indigenous affairs & 2 & 2 & 0 & 4 \\
\hline Living place & 1 & 0 & 0 & 1 \\
\hline Marine & 2 & 1 & 2 & 5 \\
\hline National defense & 0 & 1 & 0 & 1 \\
\hline $\begin{array}{l}\text { Population, borders and immigration } \\
\text { issues }\end{array}$ & 1 & 0 & 0 & 1 \\
\hline $\begin{array}{l}\text { Public education and educational } \\
\text { services }\end{array}$ & 1 & 0 & 0 & 1 \\
\hline Public function & 1 & 0 & 1 & 1 \\
\hline Public security & 0 & 0 & 1 & 1 \\
\hline Radio, television and cinematography & 2 & 0 & 0 & 2 \\
\hline Rural development & 1 & 2 & 1 & 4 \\
\hline Science in technology & 1 & 0 & 0 & 1 \\
\hline Social development & 1 & 2 & 0 & 3 \\
\hline Social Security & 0 & 1 & 0 & 1 \\
\hline Strengthening federalism & 0 & 0 & 1 & 1 \\
\hline $\begin{array}{l}\text { Surveillance of the Superior Audit of the } \\
\text { Federation }\end{array}$ & 1 & 0 & 0 & 1 \\
\hline Tourism & 1 & 1 & 0 & 2 \\
\hline Transportation & 1 & 0 & 0 & 1 \\
\hline Treasury and public credit & 2 & 1 & 1 & 4 \\
\hline Work and social security & 3 & 0 & 0 & 3 \\
\hline Youth and sport & 2 & 0 & 0 & 2 \\
\hline
\end{tabular}

Source:

Chamber of Deputies. H. Congress of the Union. List of Deputies by Parliamentary Group.

Recovered from: http://sitl.diputados.gob.mx/LXI_leg/listado_diputados_gpnp.php?tipo=TOTAL 


\section{Table 6}

Index of Legislative Effectiveness of the Federal Deputies for Relative Majority and Proportional Representation of the State of Veracruz by Ignacio de la Llave in the Chamber of Deputies. According to political party in the H. Congress of the Union. LXI Legislature.

\begin{tabular}{|l|c|c|c|c|}
\hline & PR & PAN & Total \\
\hline Initiatives presented & 46 & 21 & 19 & 86 \\
\hline Approved initiatives & 4 & 1 & 0 & 5 \\
\hline Discarded initiatives & 8 & 1 & 1 & 10 \\
\hline Pending initiatives & 34 & 19 & 18 & 71 \\
\hline \multicolumn{5}{|l|}{} \\
\hline Legislative effectiveness index & $8.7 \%$ & $4.8 \%$ & $0.0 \%$ & $5.8 \%$ \\
\hline Legislative non-effectiveness index & $17.4 \%$ & $4.7 \%$ & $5.3 \%$ & $11.6 \%$ \\
\hline Index of legislative backwardness & $73.9 \%$ & $90.5 \%$ & $94.7 \%$ & $82.6 \%$ \\
\hline Totals & $100.0 \%$ & $100.0 \%$ & $100.0 \%$ & $100.0 \%$ \\
\hline
\end{tabular}

Source:

Chamber of Deputies. H. Congress of the Union. List of Deputies by Parliamentary Group. Recovered from: http://sitl.diputados.gob.mx/LXI_leg/listado_diputados_gpnp.php?tipo=TOTAL

Technical note.

The Legislative Effectiveness Index (IEL) is an indicator that measures the ability of each deputy / party to convert the initiatives presented into law. Its formula is the following:

Legislative Effectiveness Index (IEL) $=$ [Appropriate Initiatives (IA) / Initiatives Submitted (IP)] x 100

The Legislative Non-Effectiveness Index (INEL) is an indicator that measures the inability of each deputy / party to convert the initiatives presented into law. Its formula is the following:

Index of legislative effectiveness (INEL) $=$ [Initiatives discarded (ID) / Initiatives presented (IP) $] \mathrm{x}$ 100

The Index of Legislative Non-Effectiveness (IRL) is an indicator that measures the level of lag of the initiatives of each deputy / party to convert the initiatives presented into law. Its formula is the following:

Index of legislative lag (IRL) $=[$ Initiatives pending (IPe) / Initiatives submitted (IP) $]$ x 100 


\section{Table 7}

Index of effectiveness in the legislative process of the Federal Deputies of Relative Majority and Proportional Representation of the State of Veracruz of Ignacio de la Llave in the LXI Legislature. September 2011

Number of federal deputies according to classification

\begin{tabular}{|c|c|c|c|c|}
\hline & & & \\
\hline $\begin{array}{c}\text { Index of effectiveness } \\
\text { in the legislative proce }\end{array}$ & $\begin{array}{c}\text { Institutional } \\
\text { Revolutiona- } \\
\text { ry Party } \\
\text { (PRI) }\end{array}$ & $\begin{array}{c}\text { National } \\
\text { Action Party } \\
\text { (PAN) }\end{array}$ & $\begin{array}{c}\text { Green Party } \\
\text { Ecologist of } \\
\text { Mexico } \\
\text { (PVEM) }\end{array}$ & Total \\
\hline Very efficient & 1 & 0 & 0 & 1 \\
\hline Efficient & 2 & 1 & 0 & 3 \\
\hline Little Efficient & 12 & 4 & 1 & 17 \\
\hline Inefficient & 5 & 3 & 0 & 8 \\
\hline Total & 20 & 8 & 1 & 29 \\
\hline
\end{tabular}

Percentage distribution of category identified in Federal Deputies of the State of Veracruz of Ignacio de la Llave according to Effectiveness Index in the Legislative Process, in the LXI Legislature.

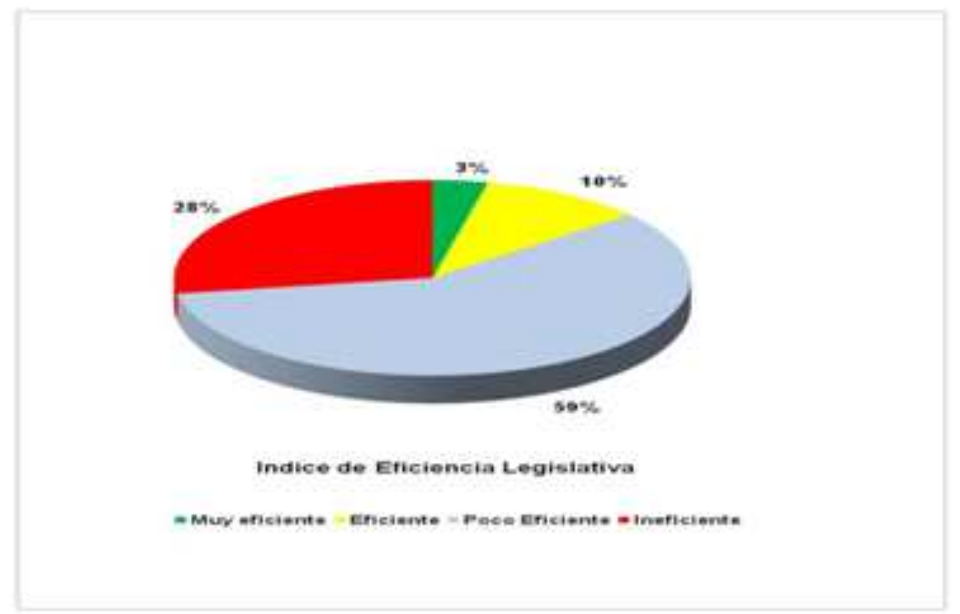

Source:

Chamber of Deputies. H. Congress of the Union. List of Deputies by Parliamentary Group. Recovered from: http://sitl.diputados.gob.mx/LXI_leg/listado_diputados_gpnp.php?tipo=TOTAL

Own estimates according to the proposed methodology for calculating the efficiency index in the legislative process (IEL). 


\section{Table 8}

Federal Deputies of Relative Majority and Proportional Representation of the State of Veracruz of Ignacio de la Llave in the LXI Legislature according to the effectiveness index in the legislative process with an Inefficient Level

September 2011

\begin{tabular}{|c|c|c|}
\hline Politic party & $\begin{array}{c}\text { Number of Federal Deputies of } \\
\text { Relative Majority and Proportional Representation with } \\
\text { Index of effectiveness in the legislative process with an } \\
\text { Inefficient Level }\end{array}$ & Percentage \\
\hline & 5 & $62.5 \%$ \\
\hline & 3 & $37.5 \%$ \\
\hline Total & 8 & $100.0 \%$ \\
\hline
\end{tabular}

\begin{tabular}{|l|l|}
\hline LEGISLATIVE EFFECTIVENESS INDEX: Inefficient \\
Technical note. \\
$\begin{array}{l}\text { In response to the result of the Legislative Effectiveness Index (IEL) } 8 \\
\text { Deputies of the LXI Legislature, representatives of the district and / or } \\
\text { circumscription of the State of Veracruz of Ignacio de la Llave, showed } \\
\text { a level of Inefficient legislative effectiveness. }\end{array}$ \\
\hline
\end{tabular}

Source:

Own calculations with information provided by the Chamber of Deputies. H. Congress of the Union. List of Deputies by Parliamentary Group. LXI Legislature. 


\section{Table 9}

Federal Deputies of Relative Majority and Proportional Representation of the State of Veracruz of Ignacio de la Llave in the LXI Legislature according to the effectiveness index in the legislative process with a Low Efficiency Level.

September 2011

\begin{tabular}{|c|c|c|}
\hline Politic party & $\begin{array}{c}\text { Number of Federal Deputies of } \\
\text { Relative Majority and Proportional Representation with } \\
\text { Index of effectiveness in legislative process with a Low } \\
\text { Efficiency Level }\end{array}$ & Percentage \\
\hline & 12 & $70.6 \%$ \\
\hline & 4 & $23.5 \%$ \\
\hline Total & 1 & $5.9 \%$ \\
\hline
\end{tabular}

\begin{tabular}{|l|l|}
\hline LEGISLATIVE EFFECTIVENESS INDEX: Little Efficient \\
$\begin{array}{l}\text { Technical note. } \\
\text { According to the result of the Legislative Effectiveness Index (IEL) } 17 \\
\text { Deputies of the LXI Legislature representatives of the district and / or } \\
\text { circumscription of the State of Veracruz of Ignacio de la Llave showed a level } \\
\text { of legislative effectiveness that was not very efficient. }\end{array}$ \\
\hline
\end{tabular}

Source:

Own calculations with information provided by the Chamber of Deputies. H. Congress of the Union. List of Deputies by Parliamentary Group. LXI Legislature. 


\section{Table 10}

Federal Deputies of Relative Majority and Proportional Representation of the State of Veracruz of Ignacio de la Llave in the LXI Legislature according to effectiveness index in the legislative process with an Efficient Level

September 2011

\begin{tabular}{|c|c|c|}
\hline Politic party & $\begin{array}{c}\text { Number of Federal Deputies of } \\
\text { Relative Majority and Proportional Representation with } \\
\text { Index of effectiveness in legislative process with an Efficient } \\
\text { Level }\end{array}$ & Percentage \\
\hline & 2 & $66.7 \%$ \\
\hline & 1 & $33.3 \%$ \\
\hline Total & 3 & $100.0 \%$ \\
\hline
\end{tabular}

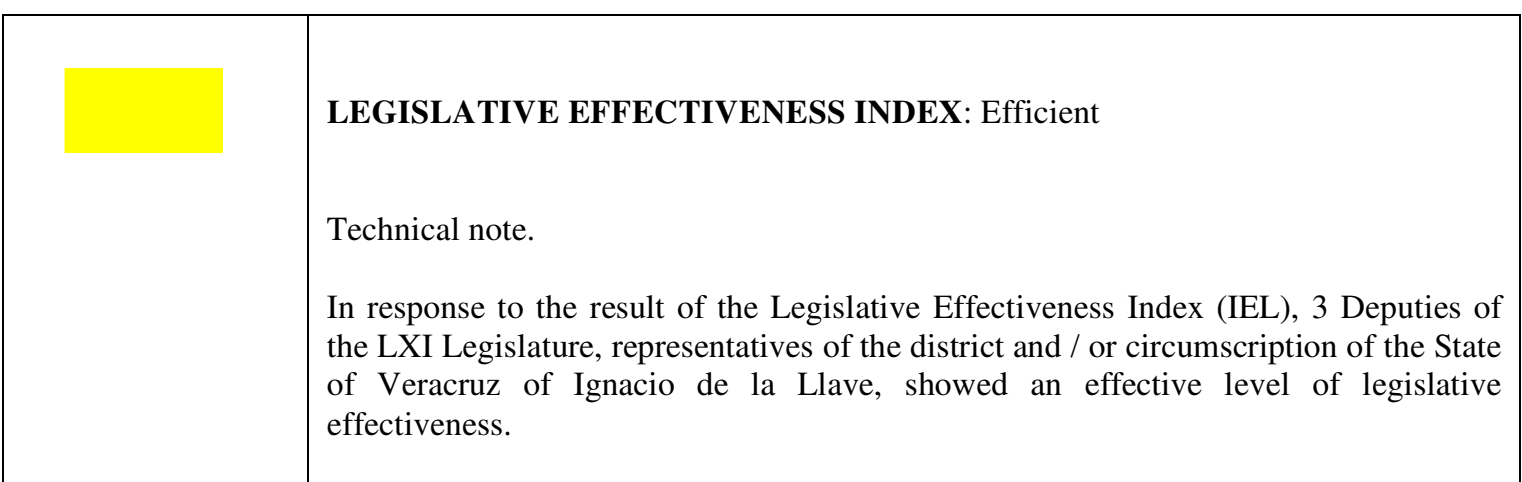

Source:

Own calculations with information provided by the Chamber of Deputies. H. Congress of the nion. List of Deputies by Parliamentary Group. LXI Legislature. 


\section{Table 11}

Federal Deputies of Relative Majority and Proportional Representation of the State of Veracruz of Ignacio de la Llave in the LXI Legislature according to effectiveness index in legislative process with a Very Efficient Level

September 2011

\begin{tabular}{|c|c|c|}
\hline Partido & $\begin{array}{c}\text { Number of Federal Deputies of } \\
\text { Relative Majority and Proportional Representation with } \\
\text { Index of effectiveness in legislative process with an Efficient } \\
\text { Level }\end{array}$ & Percentage \\
\hline & 1 & $100.0 \%$ \\
\hline Total & 1 & $100.0 \%$ \\
\hline
\end{tabular}

\begin{tabular}{|l|l|}
\hline LEGISLATIVE EFFECTIVENESS INDEX: Very Efficient \\
$\begin{array}{l}\text { Technical note. } \\
\text { Considering the result of the Legislative Effectiveness Index (IEL) 1 Deputy } \\
\text { of the LXI Legislature representatives of the district and / or circumscription } \\
\text { of the State of Veracruz of Ignacio de la Llave showed a very efficient } \\
\text { Legislative effectiveness level. }\end{array}$ \\
\hline
\end{tabular}

Source:

Own calculations with information provided by the Chamber of Deputies. H. Congress of the nion. List of Deputies by Parliamentary Group. LXI Legislature. 